\title{
David Bond and Jean Picard : Two pivotal breeders of faba bean in the 20th century
}

\section{Duc, Gerard}

2018-10

Duc , G \& Stoddard , F 2018 , ' David Bond and Jean Picard : Two pivotal breeders of faba bean in the 20th century ' , Plant Genetic Resources , vol. 16 , no. 5 , pp. 483-487 . https://doi.org/10.1017/S147926?

http://hdl.handle.net/10138/308253

https://doi.org/10.1017/S147926211800031X

unspecified

acceptedVersion

Downloaded from Helda, University of Helsinki institutional repository.

This is an electronic reprint of the original article.

This reprint may differ from the original in pagination and typographic detail.

Please cite the original version. 
David Bond and Jean Picard: Two pivotal breeders of faba bean in the $20^{\text {th }}$ century

Gerard Duc ${ }^{1}$, Fred Stoddard ${ }^{2 *}$

${ }^{1}$ UMR 1347 Agroécologie, AgroSup/INRA/UBFC, 17 rue de Sully, BP 86510, F-21000 Dijon, France

2 Department of Agricultural Sciences, Viikki Plant Science Centre, PO Box 27 (Latokartanonkaari 5-7), Fin-00014 University of Helsinki, Finland

* Corresponding author, email Frederick.stoddard@helsinki.fi, telephone +358 2941 58342, fax +358 294158582

Published in Plant Genetic Resources: Characterization and Utilization (2018) 16: 483-487. doi: $10.1017 /$ S147926211800031X 


\section{Abstract}

David Bond and Jean Picard, two leaders of European legume breeding, died within a few months of each other. On the basis of their agronomic and genetic training, they both met the challenge of breeding faba bean, a protein-rich species that had received little attention from breeders before the 1950's (Picard 1953, Bond 1957). Both made great strides at modernizing their chosen crop by developing and applying new ideas and techniques, as well as generating new methods and genetic materials. 


\section{Biographical details}

\section{David Arthur Bond, 10 June 1929 - 14 April 2017.}

David Bond was born and grew up in the English county of Norfolk, a region known for its flatness of land and its distinctive accent. He attended the village school of Alburgh, Bungay Grammar School in neighbouring Suffolk, then went to King's College Newcastle, then part of the University of Durham, to study agronomy and plant breeding until he finished his PhD in 1955.

After a year at the National Institute of Agricultural Botany, he started work at the Plant Breeding Institute, Cambridge (PBI) in 1957 and developed the country's largest faba bean breeding program. During the 1970s, when protein crops received the support of the EU, he became a strong actor within the UK and a recognized expert for EU programs. He retired in 1992 while PBI was owned by Unilever. He released many cultivars of both spring and winter beans, and virtually all of the UK area sown to winter beans was under PBI cultivars. After official retirement activity, he remained active as a scientist, writing and reading papers, and as a breeder in his home garden at Stapleford, Cambridge (Figure 1). His target then was to combine frost tolerance and large seed size in winter-hardy broad bean cultivars that he named for Robin Hood and his merry men. David had a great affection for the workhorses of his youth, along with other aspects of 1930s farming, and many of his cultivars were named for breeds of horse. He was a wonderful and inspirational mentor to junior scientists and breeders. He married Marcia in 1958 and they had two daughters and four grandchildren who brought him great joy.

\section{Jean Picard, 25 October 1924 - 16 April 2016}

He attended the village school of Neuvy-Pailloux Indre, France and in tertiary education, earned the Ingenieur Diploma of the Senior School of Agronomy (ESA) at Grignon, France, in 1948. A detailed biography is given (in French) at http://www7.inra.fr/archorales/t14-4-Jean-Picard.pdf.

He got a position of research scientist as plant breeder at INRA Versailles in 1948 where he started a program on clover. In 1955, he moved to INRA Dijon when the site of INRA Domaine d'Epoisses was developed by INRA. There, he developed large breeding programs on red clover and faba bean. He became director of the INRA Dijon plant breeding Unit in 1963 and held that role until his retirement in 1986 (Figure 2). As a director of the unit, he favoured innovative approaches, which explains the large programs on mutagenesis, in vitro culture and transposable elements on the model species Petunia hybrida by researchers in the Unit between 1965 and 1995. UNIP, the inter-professional French structure on grain legume crops, was created in 1978, and he supported it as a national general coordinator of INRA programs on grain legumes. He was among the founding members of the AEP, the European Association of Protein Crops, in 1991, and was elected as its first President at its conference in Angers, France, in the following year. He married Henriette on 29 july 1948 and they had one son and two daughters, who later provided 6 grandchildren and 4 great grandchildren of whom he was very proud. After his retirement, he lived in his home village at Neuvy-Pailloux, a charming village of the Champagne Berrichonne, taking care of his garden and bees. 


\section{Career accomplishments}

\section{Both founded as early as 1976, a strong collaborative EU network on faba bean}

For both countries, UK and France, after the Second World War, the faba bean was a minor crop, an orphan of any breeding activity and very much neglected in the modern and simple animal husbandry systems based on maize-soybean inspired from US models. The severe world soybean crisis of 1973, with a stop on the US soybean exports, initiated a new EU policy on grain legumes (pea, faba bean, lupin), supporting productions by farmers and also research on these crops. David and Jean in their respective counties were identified as major experts and correspondents for the first two symposia aiming at launching these networks: Dijon, France in November, 1976 and Bari, Italy, in April, 1978 (Bond 1976b, 1978; Picard 1976a, 1978).

They were involved in numerous European projects and contributed to the orientation of programs at the International Centre for Agricultural Research in the Dry Areas (ICARDA), then based at Aleppo, Syria. Concerned by misunderstandings around the term of "field bean", which referred to both Vicia faba and Phaseolus vulgaris, they participated in the launching of the new scientific term "faba bean" (Bond 1979).

Through 40 years of work and interdisciplinary collaborations on this then-minor crop, far from classical roads, far from private company investments and big contracts, they significantly contributed to knowledge on it. One striking characteristic in their work is that they shared many common visions on research priorities that they jointly explored in collaborative programs, exchanging plant material, ideas and students.

\section{They questioned the floral biology of faba bean with a strong interest in pollinating insects}

In order to apply modern plant breeding methods to faba bean, the floral biology had to be clarified. In his thesis in 1957 and numerous papers then followed, David and his team investigated pollination mechanisms, their genetic and morphological basis, the pollinating insect species and frequency (papers with A.E. Kambal, E.J.M. Kirby, M.H. Poulsen, G.G. Rowland and F.L. Stoddard). On his side, Jean evaluated the extent of natural outcrossing rate using hilum markers on spring or winter genotypes, demonstrating that the outcrossing rate could range from 19 to $79 \%$ (Picard, 1953) and also evaluating the relation between ovule fertilisation and pod setting (Rowland et al. 1984, 1986).

\section{They analysed the problem of yield instability and the effect of the variety type}

In the exploration of possible faba bean cultivar types in Europe (pure lines, populations and synthetics, hybrids) David and Jean promoted several international trials that evaluated genotype $x$ environment interactions. They also evaluated the positive effects of heterosis in these various cultivar types (Bond 1974, 1987 and 1989; Picard 1960 and 1982) which supported the use of synthetics and populations that exploit heterozygosity. Diverse breeding schemes were then proposed (Bond 1987, Picard 1960).

\section{They evaluated an ambitious strategy of hybrid variety breeding}

Early in his work, David discovered a progeny with $100 \%$ of outcrossing that appeared to result from cytoplasmic male sterility. Managing this cytoplasm, named 447, to allow use of the considerable 
heterosis of faba bean on-farm, occupied much of his effort for several years (Bond et al 1966) and it was generously distributed to other European breeding programs. Similarly, The French group of Berthelem and Picard found two other cytoplasms that they named 350 and 421 (Picard et al 1982, Duc et al. 1985). Neither system proved sufficiently stable to be used on a commercial scale, as both reverted to fertility under certain growing conditions such as rising temperature during flowering. The collapse of this dream was a great disappointment for both, but they rebounded and found other ways to increase yields and yield stability. Bond developed an inbred line of winter bean that was remarkably high yielding and carried a useful level of resistance to both Ascochyta blight and chocolate spot disease. It was a component of several composite cultivars.

\section{They worked on seed protein content and seed digestibility for monogastric animals}

Both investigated the genotypic and environmental factors involved in the variability of grain protein concentration and proposed parents for breeding for high values of this important trait (Bond et al 1968, Picard 1976). Picard 1976 showed the association between the white-flower character and absence of tannin in the seed. Since tannins reduce protein digestibility in monogastric animals by 8 10 percent, this trait was immediately included as an objective in the breeding programs of both INRA and PBI (Bond 1976; Picard 1976). In France, this in the release by Jean of the first zero-tannin cultivar, Blandine, in 1985. White-flowered winter bean cultivars Polar, Glacier and Silver were released from 1980 onward, but there was a yield penalty associated with low tannin, so they did not become widespread. Other potential antinutritional factors were evaluated in both countries, particularly vicine-convicine in order to explore the possibility of reducing them by breeding (Bond and Duc, 1993).

\section{They were convinced of the role of faba bean in crop rotations}

They were convinced of the complementarity between spring and winter faba bean cultivars in order to enlarge cropping system options in UK and French agricultures. Consequently, both programs used sources of frost hardiness, with contrasted earliness and plant architectures, in order to develop new autumn-sown germplasm. In the agriculture of the $19^{\text {th }}$ century in both France and the UK, winter faba beans were important (Bond and Crofton 1999), and some remarkably highly frost-resistant material developed, such as the population "Côte d'Or" (Picard et al 1985). This population has been used as a parent in many European breeding programs. This work resulted especially in UK, in the release of many winter cultivars, many named for dog or workhorse breeds.

\section{They left many valuable genetic resources for future breeding programs}

Throughout their work they explored many traits of interest in faba bean breeding, such as aphid or disease susceptibility (Bond et al 1978, 1994, Picard 1978). They retired just at the time when molecular biology tools were entering the breeding work but from discussions with them, we know that they were interested in the potential of these new tools. David wrote several book chapters about faba bean breeding, and both breeders left rich collections of genetic resources, a spirit of collaboration, strong data and cogent arguments about the value and potential of legumes (including faba bean) for European agriculture. They launched the careers of several young scientists who have sought to carry on their work and develop this crop in new ways that will continue to feed the world. We remain grateful for all that they generously built for the legume research community that continues today in our various networks. 
David and Jean were strongly involved in the national registration system of cultivars in their respective countries, and also when the European catalogue was launched in interaction with national ones. They were key contributors to the criteria that are used to distinguish or evaluate agronomic performance and nutritional values of new faba bean cultivars (Crofton et al. 1998, 2000).

They trained a number of students, including the authors of this paper, and worked with many international visitors. Their crop is in better shape around the world because of their efforts. 


\section{Acknowledgments}

We thank Sylvia Bond and Mervyn Pope for useful information about David Bond's life and career.

\section{References}

Bond DA (1957) Investigations of the breeding system of Vicia faba. Ph.D. thesis, University of Durham, U.K.

Bond DA (1974) Die Züchtung von hybrid und synthetischen sorten Ackerbohnen in Cambridge. Göttingen Pflanzenzüchter Seminar 2: 39-62

Bond DA (1976a) In vitro digestibility of the testa in tannin-free field beans (Vicia faba L.). Journal of Agricultural Science, Cambridge, 86: 561-566

Bond DA (1976b) Breeding for zero-tannin and protein yield in field beans (Vicia faba L.). Pp. 348-353 In: EEC Seminar on Protein quality from leguminous crops, Dijon, France, November 3-5, 1976. EU Commission Agricultural Research Series, EUR 5686.

Bond DA (1979) English names of Vicia faba: broadbean, field bean or faba bean? FABIS Newsletter 1: 15.

Bond DA (1987) Recent developments in breeding field bean (Vicia faba L.). Plant Breeding 99: 1-26.

Bond DA (1989) Prospects for commercialization of $F_{1}$ hybrid field beans Vicia faba L. Euphytica 41: 81-86.

Bond DA and Crofton GRA (1999) History of the winter beans in the UK. Journal of the Royal Agricultural Society of England 160: 200-209.

Bond DA and Duc G (1993) Plant breeding as a means of reducing antinutritional factors in grain legumes. Pp. 379-396 In: Muzquiz M, Hill GD, Cuadrado C, Pedrosa MM and Burbano C (eds). Recent Advances of Research in Antinutritional Factors in Legume Seeds and Oilseeds (EAAP scientific series 110). Wageningen, Netherlands: Wageningen Academic Publishers.

Bond DA and Kirby EJM (1999) Anthophora plumipes (Hymenoptera: Anthophoridae) as a pollinator of broadbean (Vicia faba major). Journal of Apicultural Research 38: 199-203.

Bond DA and Lowe HJB (1978) Resistance to Aphis fabae Scop. in field beans (Vicia faba L.): plant breeding and field performance. Pp. 103-121 In: Bond DA, Scarascia-Mugnozza GT and Poulsen MH (Eds). Some current research on Vicia faba in Western Europe. A seminar in the EEC Programme of Coordination of Research on Plant Proteins, held at Bari, Italy, on 27-29 April, 1978. Luxembourg: Commissionof the European Communities.

Bond DA and Poulsen MH (1983) Pollination. Pp. 77-101 In: Hebblethwaite PD (ed.), The Faba Bean, a Basis for Improvement. London, UK: Butterworth.

Bond DA, Fyfe JL and Toynbee-Clarke G (1966) Male sterility with a cytoplasmic type of inheritance in field beans. Journal of Agricultural Science, Cambridge, 66: 359-367 
Bond DA and Toynbee-Clarke G (1968) Protein content of spring and winter varieties of field beans (Vicia faba L.) sown and harvested on the same dates. Journal of Agricultural Science, Cambridge, 70 : 403-404.

Bond DA, Jellis GJ, Rowland GG, Le Guen J, Robertson LD, Khalil SA and Li L-J (1994) Present status and future strategy in breeding faba beans (Vicia faba L.) for resistance to biotic and abiotic stresses Euphytica 73: 151-166.

Crofton GRA and Bond DA (1998) A review of the genetics of seed coat colour and hilum colour in field bean (Vicia faba L. (Partim)) with comments on some implications for national listing and certification. Plant Varieties and Seeds 11: 97-106

Crofton GRA, Bond DA and Duc G (2000) Potential seed multiplication problems arising from existence of two genes for the absence of tannin in Vicia faba L. Plant Varieties and Seeds 13: 131139

Duc G, Picard J, Le Guen J and Berthelem P (1985) Note on the appearance of a new nucleocytoplasmic male sterility in Vicia faba appeared after mutagenesis. Agronomie 5: 851-854

http://www7.inra.fr/archorales/t14-4-Jean-Picard.pdf

Picard J (1953) Données sur l'amélioration de la féverole de printemps Vicia faba L. Annales de l'Amélioration des Plantes, 2: 121-153

Picard J (1960) Recherches sur la féverole. Annales de l'Amélioration des Plantes, 23: 57-106

Picard J (1976a) Some results dealing with breeding for protein content in Vicia faba L. Pp. 339- 353 In: EEC Seminar on Protein quality from leguminous crops, Dijon, France, November 3-5, 1976. EU Commission Agricultural Research Series, EUR 5686.

Picard J (1976b) Aperçu sur l'hérédité du caractère absence de tanins dans la graine de féverole (Vicia faba L.). Annales de l'Amélioration des Plantes 26: 101-106.

Picard J (1978) Some reflections on problems and prospects in Vicia faba breeding. Pp. 23-37 In: Bond DA, Scarascia-Mugnozza GT and Poulsen MH (Eds). Some current research on Vicia faba in Western Europe. A seminar in the EEC Programme of Coordination of Research on Plant Proteins, held at Bari, Italy, on 27-29 April, 1978. Luxembourg: Commissionof the European Communities.

Picard J, Berthelem P, Duc G and Le Guen J (1982) Male sterility in Vicia faba. Future prospects for hybrid cultivars. Pp 53-69 In: Hawtin G and Webb C (eds). Faba Bean Improvement. The Hague, Netherlands: Martinus Nijhoff.

Picard J, Duc G and Pelletier R (1985) "Côte d'Or" a highly frost resistant population of Vicia faba. FABIS Newsletter 13: 11-12

Rowland G, Duc G and Picard J (1984) The effect of environment, apex excision and flower removal on fertility components of faba bean. Canadian Journal of Plant Science, 64: 95-103.

Rowland G, Duc G and Picard J (1986) Fertility components in a faba bean line near isogenic for male sterility. Canadian Journal of Plant Science, 66: 235-239 
Stoddard FL and Bond DA (1987) The pollination requirements of the faba bean (Vicia faba L.). Bee World 68: 144-152. 


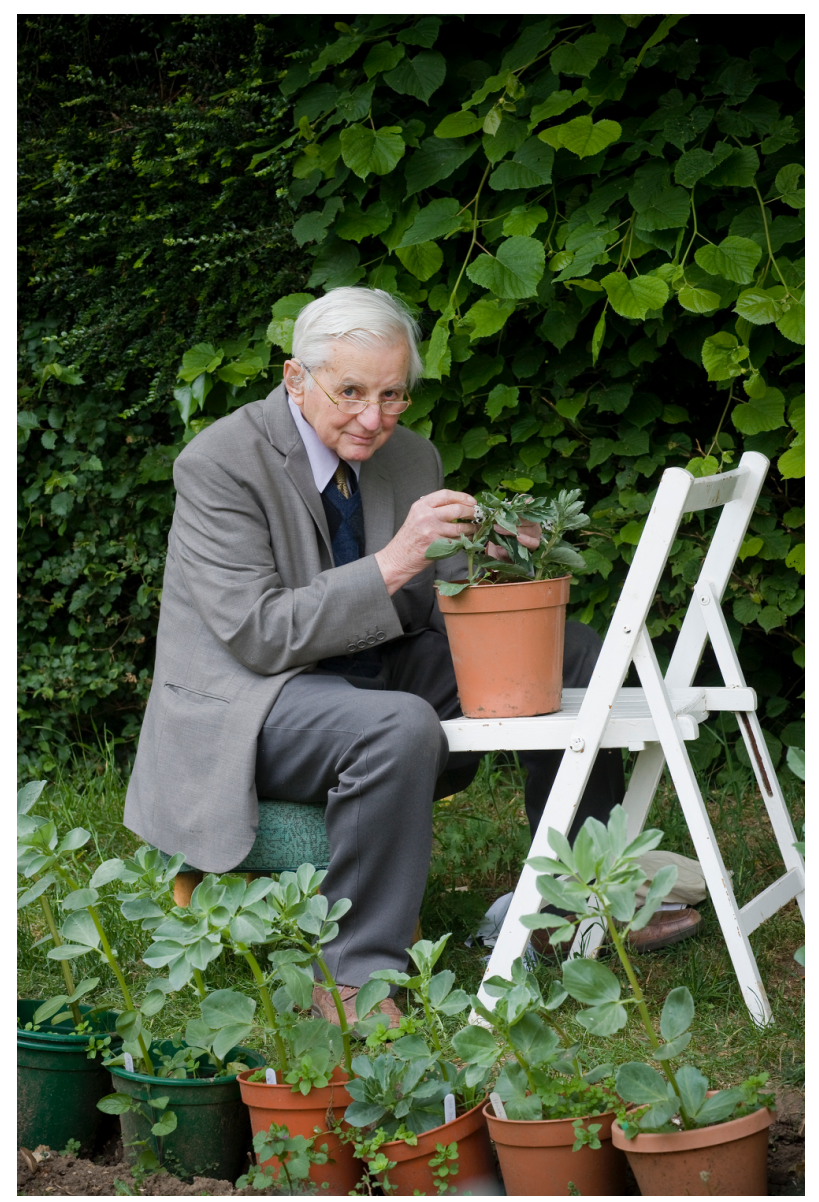

Figure 1. David Bond in his garden, still cross-pollinating beans in his $80^{\text {th }}$ year.

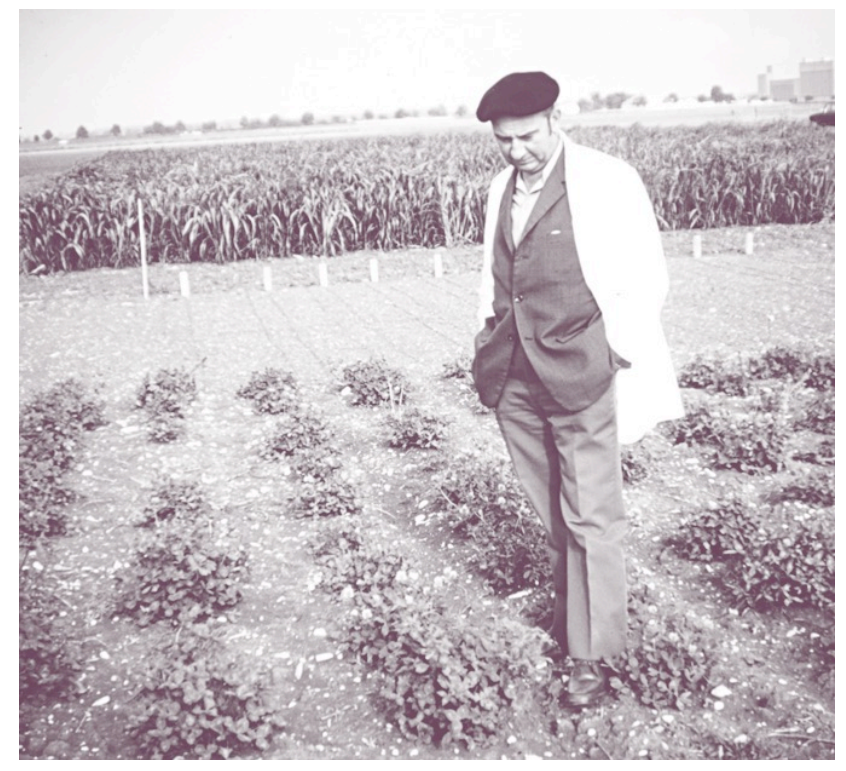

Figure 2. Jean Picard in his field plots, aged about 40. 